\title{
Influence of the Technological Process on the Biochemical Composition of Fresh Roe and Bottarga from Liza ramada and Mugil cephalus
}

\author{
Francesco Corrias ${ }^{1}$, Alessandro Atzei ${ }^{1}$, Angelica Giglioli ${ }^{2}$, Viviana Pasquini ${ }^{2}$, Alessandro Cau ${ }^{2}$, \\ Piero Addis $2\left(\mathbb{D}\right.$, Giorga Sarais ${ }^{1}(\mathbb{D}$ and Alberto Angioni $1, *(\mathbb{C})$ \\ 1 Department of Life and Environmental Science, Food Toxicology Unit, University of Cagliari, \\ University Campus of Monserrato, SS 554, 09042 Cagliari, Italy; francesco.corrias@unica.it (F.C.); \\ alessandro.atzei@unica.it (A.A.); gsarais@unica.it (G.S.) \\ 2 Department of Life and Environmental Science, Biology Section, University of Cagliari, \\ via Tommaso Fiorelli 2, 09126 Cagliari, Italy; giglioli.angelica@gmail.com (A.G.); \\ vivi.pasquini@yahoo.it (V.P.); alessandrocau@unica.it (A.C.); addisp@unica.it (P.A.) \\ * Correspondence: aangioni@unica.it; Tel.: +39-0706758615; Fax: +39-0706758612
}

Received: 11 August 2020; Accepted: 30 September 2020; Published: 4 October 2020

\begin{abstract}
Bottarga is a high-priced delicacy with high nutritional value, and, in Italy, bottarga from mullets has been recognized to be a traditional food product. The flathead grey mullet Mugil cephalus and the thinlip grey mullet Liza ramada are the main cultured grey mullets in the Mediterranean Sea. In this study, fresh roe and bottarga from these two species were investigated to evaluate the influence of the technological process and the species on their biochemical composition and health advantages. The $1 \mathrm{~h} / 200 \mathrm{~g}$ salting-out step did not increase the levels of $\mathrm{NaCl}$ in the bottarga, although it highly decreased the levels of some heavy metals like $\mathrm{Cu}$ and Al. Processing of fresh roe in bottarga led to an essential modification of the lipid fraction, following a general series of monousatturated fatty acid (MUFA) $>$ poliunsutturated fatti acid (PUFA) > saturated fatty acid (SAFA) and an increase in both $\omega 3$ and $\omega 6$ in Liza ramada. Moreover, bottarga showed higher levels of squalene and cholesterol and an increased Essential Amino Acid/Total Amino Acid ratio (EAA/TAA) in both species. In addition to the nutritional benefits for the consumer, the process proposed in this study may represent a reliable tool for local producers to obtain a final bottarga with both a reproducible biochemical composition and organoleptic characteristics.
\end{abstract}

Keywords: bottarga; salting-out; food processing; lipid composition; squalene; metals; PCA

\section{Introduction}

Grey mullets (Mugilidae) are cosmopolitan euryhaline species that inhabit coastal, estuarine, and freshwater environments proximal to high human populations [1]. Due to their cosmopolitan distribution, they represent a popular target for commercial fisheries, reaching a whole production of 698,293 $t$ in 103 countries in 2013 [1]. In the Mediterranean area, the main cultured grey mullet species are the thinlip Liza ramada (Risso, 1826) and the flathead Mugil cephalus (Linneo, 1758) [2]. In Italy, mullet farming is almost entirely based on extensive techniques, with coastal lagoons and semi-intensive ponds being restocked with wild juveniles [3]. M. cephalus is the dominant aquaculture species; it can reach a length of up to $120 \mathrm{~cm}$ (weight up to $5 \mathrm{~kg}$ ) with a maximum reported age of 16 years, making it the prevalent mullet species [4], while L. ramada has a lower growth rate, reaching a body length of up to $70 \mathrm{~cm}$ (weight $2.9 \mathrm{~kg}$ ) with a maximum reported age of 8 years [4]. Adults of $L$ ramada and $M$. cephalus live in large schools with different habits. L. ramada prefers surface water over sandy and dense Posidonia oceanica vegetation, while M. cephalus habitat is mostly represented 
by muddy bottoms and rocky seabed with vegetation. Usually, they move from the sea into brackish coastal lagoons, where they spend most of their growing phase, before migrating back to the sea to spawn [1]. Grey mullets provide several different foodstuff, including fresh fish fillets and processed roe, known as bottarga or boutargue in Europe or karasumi in Asia, for human consumption $[5,6]$. Bottarga is obtained from the ripening ovaries after salting and air drying. In Sardinia, salted mullet roe obtained from M. cephalus and L. ramada are considered a delicacy, equivalent to sturgeon caviar, and can reach 200 euros $/ \mathrm{kg}$ when obtained from local Sardinian mullets. In Italy, bottarga from mullets has been recognized to be a traditional food product, and Sardinia is the main producing region, assuming an important role in the local, national, and international market [7-9]. M. cephalus fish of 1.5 to $2.5 \mathrm{~kg}$ produce fresh gonads ranging 300-600 g, which, after processing, yield a bottarga of 200-400 $\mathrm{g}$ weight and final thickness around $1.6 \mathrm{~cm}$, whereas L. ramada fresh gonads can reach $50 \mathrm{~g}$ and a final bottarga of around $30 \mathrm{~g}$ weight and $0.8 \mathrm{~cm}$ thickness. The organoleptic characteristics of bottarga are related to an intense and sweet flavor, with an evident salty note but round and balanced with a slightly bitter and spicy aftertaste. Bottarga has a low level of water activity (Aw); therefore, it is not the ideal breeding ground for mold and microorganisms. The principal negative aromas in bottarga are represented by muddy and musty odors related to the presence of geosmin and 2-methylisoborneol, two compounds produced by cyanobacteria and actinomycetes, which grow in restricted and closed pounds [10]. A few papers have reported the biochemical composition of bottarga from different fishing areas [11], carried out by GC-MS and NMR techniques [12-15]. Moreover, some papers have reported the effect of the processing method on the proximate to monitor spoilage during cold storage [16] and on the rheological characteristics [17]. No paper was found in the literature reporting the influence of the processing steps on the biochemical composition of the bottarga and the composition of L. ramada in comparison with M. cephalus. The purpose of this paper is to analyze the biochemical composition and quality characteristics of ripe ovaries, fresh and after processing in bottarga, from two different grey mullet species grown in the Cabras lagoon (Sardinia, Italy). Moreover, since the two grey mullets show different behavioral attitudes, the presence of the off-flavors geosmine and 2-methylisoborneol and the concentration of some metals and metalloids were also investigated.

\section{Materials and Methods}

\subsection{Sample Collection}

Ten samples of Mugil cephalus and Liza ramada migrating ripe females were collected in 2019 (late summer) from the Cabras lagoon ( $39^{\circ} 54^{\prime} 46.87^{\prime \prime} \mathrm{N}-8^{\circ} 30^{\prime} 33.20^{\prime \prime} \mathrm{E}$, Gulf of Oristano) [18]. This wetland area, one of the major brackish systems of the western Mediterranean, is traditionally devoted to fishing and aquaculture practices $[19,20]$. Samples were captured using low-frequency, pulsed DC electrofishing. Stunned ripe female fish of appropriate weight and size were immediately killed by spiking the brain [21], held in iceboxes, and brought to the laboratory within three hours for the processing step.

\subsection{Processing Step}

Mullets were measured for total length $(\mathrm{TL}, \mathrm{cm})$ and body weight $(\mathrm{BW}, \mathrm{kg})$. Then, the fish were dissected using a sharp stainless-steel scalpel and the ovaries were removed, avoiding the vitelline membrane breaking. The two fresh ovaries from each fish were cleaned and freed from the gonadal artery. Thereafter, they were separated, weighed, and one was used for the analysis of the fresh gonads (control sample), and the other for the processing in bottarga.

Gonad processing involves a salting-out step ( $1 \mathrm{~h} / 200 \mathrm{~g}$ roes; $4 \%$ weight decrease). After that, the salt residues were removed, and gonads were placed between two wooden boards and pressed for one day ( $6 \%$ weight decrease). The wooden boards were previously sanitized with a solution of $\mathrm{NaClO}$ at $4 \%$. After pressing, the gonads were left at atmospheric temperature $\left(20^{\circ} \mathrm{C}\right)$ and constant humidity $(53 \%)$ and rotated each day in order to facilitate water evaporation till they reached a $30 \%$ 
weight loss. The dehydration step in the open air took 5-7 days. Bottarga samples were stored in vacuum containers at $5{ }^{\circ} \mathrm{C}$ till analysis. Each analysis was performed in triplicate, a total of 30 samples of fresh gonads and bottarga were analyzed in the study.

\subsection{Chemicals}

Ethylic ether, petroleum ether, hexane, methanol, and chloroform were the ultra-residue solvents of analytical grade, purchased from Merck (Darmstadt, Germany). $\mathrm{NaCl}, \mathrm{MgSO}_{4}$ anhydrous and $\mathrm{Na}_{2} \mathrm{SO}_{4}$ anhydrous $\mathrm{KOH}$ and $\mathrm{KCl}$ were of analytical grade (Sigma Aldrich Chemie, Darmstad, Germany). Geosmin (GSM), 2-methylisoborneol (2-MIB; purity $\geq 95 \%$ ), MSTFA, squalene, cholesterol, and dodecanone were analytical grade standards (Fluka, Sigma Aldrich Chemie, Germany). The amino acid mix solution was purchased from Merck (Darmstadt, Germany). The marine oil FAME mix analytical standard was purchased from Restek (Bellefonte, PA, USA). $\mathrm{HNO}_{3} 67-69 \%, \mathrm{H}_{2} \mathrm{O}_{2} 30 \%$ (Carlo Erba, Milan, Italy), $\mathrm{HCl} 37 \%$ super pure quality (Romil Spa, Cambridge, $\mathrm{UK}$ ) and standards of $\mathrm{Al}$, As, B, Ba, Be, Cd, Co, Cr, Cu, Fe, Hg, Mn, Mo, Ni, Pb, Sb, Sn, Sr, Te, Ti, V, and $\mathrm{Zn}$ were of ICP grade (Carlo Erba Reagents, Milan, Italy). Double-deionized water, with a conductivity of less than $18.2 \mathrm{M} \Omega$, was obtained with a Milli-Q system (Millipore, Bedford, MA, USA).

\subsection{Moisture and Ash}

Briefly, $5 \mathrm{~g}$ of homogenized samples (fresh gonads and bottarga) were weighed and dried at $100{ }^{\circ} \mathrm{C}$ until a constant weight was achieved $(\sim 24 \mathrm{~h})$ for moisture determination. Samples were then heated to $500{ }^{\circ} \mathrm{C}$ in a porcelain crucible for five hours for carbonization and ash analysis. Moisture and ash determinations were calculated as a percentage of the fresh product.

\subsection{Metals and Metalloids}

Metals and metalloids were analyzed according to Corrias et al. (2020) [22]. Briefly, ashes obtained by carbonization were mineralized in a microwave CEM Mars6 system (CEM Italia, Bergamo, Italy). About $0.2 \mathrm{~g}$ of ashes was precisely weighed, and then $10 \mathrm{~mL}$ of a mixture of $\mathrm{HNO}_{3}$ and $\mathrm{HCl}$ (molar ratio 1:3) and $1 \mathrm{~mL}$ of $\mathrm{H}_{2} \mathrm{O}_{2}$ were added. After the mineralization program, the solutions were transferred into a 10-mL flask and brought to volume with Milli-Q water, filtered through a $0.45 \mu \mathrm{m}$ nitrocellulose membrane filter (Whatman, Milan, Italy) in another flask and, finally, subjected to analysis. Control solvent samples were simultaneously prepared to avoid false-positives and contamination during analysis. $\mathrm{Hg}$ and As sample preparation was carried out using an Agilent VGA-77 (Agilent, Milan, Italy) according to Agilent application notes [23,24]. A Varian 710ES ICP Optical Emission Spectrometer (Agilent, Milan, Italy) for the simultaneous analysis of 22 metals and metalloids was used. Operating conditions: radiofrequency (RF) generator power 1.2, frequency $40 \mathrm{MHz}$; argon (99.996\% purity) was used for plasma (15.5 L/min), nebulizer (200 Kpa), and optic supply $(1.5 \mathrm{~L} / \mathrm{min})$. The sample uptake delay was $30 \mathrm{~s}$, and the instrument stabilization delay was $15 \mathrm{~s}$. Power and pressure applied were $600 \mathrm{~W}$ and 100 PSI for $13 \mathrm{~min}$. Each measurement was made in triplicate. The limit of quantitation (LOQ) was calculated as ten times the standard deviation reading of the blank sample signal [25]. Calibration curves were calculated on five points starting from the LOQ value and were considered acceptable for $r^{2} \geq 0.990$.

\subsection{Analysis of the Lipid Fraction}

\subsubsection{Total Lipid}

Briefly, $1 \mathrm{~g}$ of homogenized sample (fresh gonads and bottarga) was accurately weighed in an extraction thimble. Lipids were extracted using the rapid extraction system for solid-liquid extraction Soxtherm (C-Gerhardt, Analytical Systems, Konigswinter, Germany) with $150 \mathrm{~mL}$ mixture of ethylic ether/petroleum ether (1/1), according to the AOAC method [26]. 


\subsubsection{Squalene and Cholesterol}

Briefly, $0.5 \mathrm{~g}$ of homogenized sample (fresh gonads and bottarga) was weighed in a screw-capped vial, with $2 \mathrm{~mL}$ of hexane, vortex-mixed for $3 \mathrm{~min}$ and centrifuged for $10 \mathrm{~min}$ at $4000 \mathrm{rpm}$ and $10^{\circ} \mathrm{C}$. The organic phase was recovered and diluted 1/10 with hexane. The analyses were carried out using a Varian CP 3800 gas chromatograph (Varian, Inc., Palo Alto, CA, USA) coupled with a Varian CP 7800 autosampler and a Varian 2000 ITMS. The column was a DB-5MS (5\% phenylmethyl polysiloxane, $30 \mathrm{~m} \times 0.25 \mathrm{~mm}$, film thickness $0.25 \mu \mathrm{m} ; \mathrm{J} \& W$ Scientific Fisons, Folsom, CA, USA). The injector and the MS interface were set at 280 and $180^{\circ} \mathrm{C}$, respectively. The oven was programmed as follows: $60^{\circ} \mathrm{C}$ $(1 \mathrm{~min})$ to $300^{\circ} \mathrm{C}\left(3^{\circ} \mathrm{C} / \mathrm{min}\right)$. Helium was the carrier gas at $1 \mathrm{~mL} / \mathrm{min}$. The sample $(1 \mu \mathrm{L})$ was injected in splitless mode ( $30 \mathrm{~s})$. The data were processed using the Varian ChemStation. ITMS conditions were as follows: ionization voltage $70 \mathrm{eV}$, scan rate $1.6 \mathrm{scan} / \mathrm{s}$, mass range $40-650$, ionization source at $180^{\circ} \mathrm{C}$. Quantitative ions were $m / z 386$ and 69 for cholesterol and squalene, respectively. Qualifiers ions were $\mathrm{m} / \mathrm{z} 353,301$, and 275 for cholesterol and $m / z$ 410, 69, and 95 for squalene. A five-point calibration curve was prepared from authentic standards in the range of $1.0-100 \mathrm{mg} / \mathrm{kg}$.

\subsubsection{Fatty Acid}

Briefly, $5 \mathrm{~g}$ of homogenized samples (fresh gonads and bottarga) was accurately weighed in a screw-capped tube of $40 \mathrm{~mL}$, plus $10 \mathrm{~mL}$ of hexane, $3 \mathrm{~g}$ of $\mathrm{NaCl}$, and $2 \mathrm{~g}$ of $\mathrm{MgSO}_{4}$. The tube was agitated for $2 \mathrm{~min}$ in a vortex and for $15 \mathrm{~min}$ in a rotatory shaker. The tubes were then centrifuged at $4000 \mathrm{rpm}$ for $10 \mathrm{~min}\left(10^{\circ} \mathrm{C}\right.$ temperature). Transesterification was carried out as follows: $500 \mu \mathrm{L}$ of hexane extract plus $200 \mu \mathrm{L}$ of alcoholic potash $(\mathrm{KOH} 2 \mathrm{~N}$ in $\mathrm{MeOH})$ were heated and agitated in a vortex for $4 \mathrm{~min}$. The organic phase was then transferred to another vial and injected in GC-MS for the analysis. Analysis was carried out using a gas chromatograph TRACE GC ULTRA and a Single Quad DSQ mass detector (Thermo Finnigan, Milan, Italy), equipped with a COMBI PAL autosampler (CTC Analytics, Zwingen, Switzerland) and a split/splitless injector. The analytical column was a Varian Factor Four VFWAX $(60 \mathrm{~m} \times 0.25 \mathrm{~mm}$ i.d. $\times 0.25 \mu \mathrm{m}$ film thickness; Varian, Milan, Italy). Helium was the carrier gas at $1 \mathrm{~mL} / \mathrm{min}$. The sample of $1 \mu \mathrm{L}$ was injected in splitless mode $(1 \mathrm{~min})$. The mass spectrometer detector was operated in electron ionization (EI) positive mode, with a solvent delay of $5.5 \mathrm{~min}$. Injector, ion source, and transfer line temperatures were at 50,200 , and $250{ }^{\circ} \mathrm{C}$, respectively. The oven was programmed as follows: $90^{\circ} \mathrm{C}(1 \mathrm{~min})$, raised to $160{ }^{\circ} \mathrm{C}\left(3^{\circ} \mathrm{C} / \mathrm{min}\right)$, then $198^{\circ} \mathrm{C}\left(1{ }^{\circ} \mathrm{C} / \mathrm{min}\right)$, and further to $250^{\circ} \mathrm{C}\left(5^{\circ} \mathrm{C} / \mathrm{min}\right)$, and then held for $15 \mathrm{~min}$. Peak identification was made, comparing full mass spectra (50-550 $\mathrm{m} / \mathrm{z}$ ) and retention times (r.t.) from authentic standards and the NIST MS spectra library.

\subsection{Analysis of Protein Fraction}

\subsubsection{Total Protein}

Total protein was analyzed according to the Kjeldahl method. Briefly, $0.5 \mathrm{~g}$ of well-homogenized sample was weighed in the Speed-Digester flasks; $20 \mathrm{~mL}$ of concentrated $\mathrm{H}_{2} \mathrm{SO}_{4}(96 \%), 0.5 \mathrm{~g}$ of sodium sulfate, and a tip of copper sulfate were added to the mineralization flask. After mineralization, the solution was left to cool, and $50 \mathrm{~mL}$ of $\mathrm{H}_{2} \mathrm{O}$ MilliQ were added. When the solution reached a light blue color, the flask was inserted into the distillation unit, and a concentrated solution of $\mathrm{NaOH}$ was added directly to the distiller and subjected to distillation until a brownish-black color was obtained. Then, $100-150 \mathrm{~mL}$ were collected, and a known quantity of $\mathrm{H}_{2} \mathrm{SO}_{4} 0.5 \mathrm{~N}$ plus few drops of methyl red were added. After distillation, quantitative analysis was made by acid-base titration using $0.5 \mathrm{~N} \mathrm{NaOH}$.

$$
\% \text { protein }=((a-b) * c * 100 * K) / g \text { sample }
$$

a: $\mathrm{mL}$ of $0.5 \mathrm{~N} \mathrm{H}_{2} \mathrm{SO}_{4}$ added to the collection flask; b: $\mathrm{mL}$ of titrant used $(\mathrm{NaOH} 0.5 \mathrm{~N})$; c: conversion factor $\mathrm{ml}$ of $\mathrm{H}_{2} \mathrm{SO}_{4} 0.5 \mathrm{~N}$ in $\mathrm{g}$ of nitrogen (0.007); $\mathrm{K}$ : general nitrogen-protein conversion factor (6.25). 


\subsubsection{Amino Acid Analysis}

Briefly, $100 \mu \mathrm{g}$ of homogenized samples (fresh gonads and bottarga) was weighed in an Eppendorf tube, and $250 \mu \mathrm{L}$ of $\mathrm{MeOH}$ and $125 \mu \mathrm{L}$ of $\mathrm{CHCl}_{3}$ were added. The tube was stored for $1 \mathrm{~h}$ in the dark and shaken in a vortex every $15 \mathrm{~min}$. After adding $380 \mu \mathrm{L}$ of $\mathrm{CHCl}_{3}$ and $90 \mu \mathrm{L}$ of $\mathrm{KCl} 0.2 \mathrm{M}$, the tube was shaken for $3 \mathrm{~min}$ in a vortex and centrifuged at $14,000 \mathrm{rpm}$ and $4{ }^{\circ} \mathrm{C}$ for $10 \mathrm{~min}$. The hydrophilic phase was transferred in another vial and dried under a gentle nitrogen stream. For derivatization, $50 \mu \mathrm{L}$ of methoxamine pyridine solution $(104 \mathrm{mg} / \mathrm{L})$ was added in the vial, and the solution was left in the dark for $17 \mathrm{~h}$. After that, $100 \mu \mathrm{L}$ of MSTFA was added, followed by $3 \mathrm{~min}$ in a vortex and $1 \mathrm{~h}$ in the dark. Before gas-chromatography analysis, $600 \mu \mathrm{L}$ of dodecanone solution $(20 \mathrm{mg} / \mathrm{L})$ in hexane (IS) was added. Samples were injected $(1 \mu \mathrm{L})$ in splitless mode into a 6850 gas-chromatograph coupled with a 5973 mass-spectrometer (Agilent Technologies, Santa Clara, CA, USA). The injector temperature was $200{ }^{\circ} \mathrm{C}$, and the gas flow rate was $1 \mathrm{~mL} / \mathrm{min}$. The column was a DB5-MS capillary fused silica column $(0.25 \mu \mathrm{m}, 30 \mathrm{~m} \times 0.25 \mathrm{~mm}$ ID; J\&W Scientific, Folsom, CA, USA). The temperature program was $\mathrm{T}=050^{\circ} \mathrm{C}(10 \mathrm{~min})$, then increased to $300{ }^{\circ} \mathrm{C}$ at $10^{\circ} \mathrm{C} / \mathrm{min}$ and held for $10 \mathrm{~min}$. Ionization was at $70 \mathrm{eV}$ in $\mathrm{EI}+$, over $\mathrm{m} / \mathrm{z} 50-550$ mass range. Identification of free amino acids was performed using the standard amino acid mixture (alanine, arginine, aspartic acid, glutamic acid, glycine, histidine, isoleucine, leucine, lysine, methionine, phenylalanine, proline, serine, threonine, tyrosine, valine, and cystine) and the NIST08 mass spectra library.

\subsection{Geosmine and 2-Methylisoborneol}

Analyses were carried out according to Angioni et al. [10], briefly: $5 \mathrm{~g}$ of homogenized samples were weighed in a screw-capped tube with $3 \mathrm{~g}$ of $\mathrm{NaCl}, 10 \mathrm{~mL}$ of hexane, and $2 \mathrm{~g}$ of $\mathrm{MgSO}_{4}$ anhydrous. The tube was stirred in a vortex ( $2 \mathrm{~min})$, and rotary shaker (15 $\mathrm{min})$; after that, it was centrifuged at $4000 \mathrm{rpm}\left(10 \mathrm{~min}, 10^{\circ} \mathrm{C}\right)$. Off-flavors were analyzed in GC/ITMS. The quantitative determination was made in SIM mode using $\mathrm{m} / \mathrm{z} 95$ and 112 for 2-MIB and GSM, respectively.

\subsection{Statistical Analysis}

Analysis of variance (ANOVA) was carried out with the software XLSTAT (Addinsolf LTD, New York, NY, USA, Version 19.4). Mean comparisons of the effects of treatments were calculated by Fisher's least significant difference test at $p \leq 0.05$. Analysis data sets were imported into SIMCA 14 (Umetrics AB, Umea, Sweden) for principal component analysis (PCA) [27].

\section{Results}

\subsection{Physicochemical Analysis}

M. caephalus and L. ramada fish ranged $1.80 \pm 0.50$ and $0.75 \pm 0.45 \mathrm{~kg}$ in weight and $49.80 \pm 3.70$ and $26.74 \pm 1.75 \mathrm{~cm}$ in length, respectively. The water content was $47.6 \pm 8.4 \%$ and $50.7 \pm 0.4 \%$ $(\mathrm{g} / 100 \mathrm{~g} \pm \mathrm{RSD})$ in fresh gonads and $13.6 \pm 3.4 \%$ and $24.8 \pm 1.3 \%(\mathrm{~g} / 100 \mathrm{~g} \pm \mathrm{RSD}, \mathrm{FW})$ in bottarga for $L$. ramada and M. cephalus, respectively (Table 1). The ash content was $5.9 \pm 7.0 \%$ and $4.7 \pm 14.7 \%$ on fresh gonads and $8.6 \pm 4.5 \%$ and $7.2 \pm 1.6 \%(\mathrm{~g} / 100 \mathrm{~g} \pm \mathrm{RSD}, \mathrm{FW})$ on bottarga for $L$. ramada and M. cephalus, respectively (Table 1 ). The processing step moderately affected the mineral concentration in the gonads. Dry salting for one hour permitted the diffusion of a moderate amount of salt in the gonads of around $44 \%$ of total minerals, acting mainly as a dehydrating agent. 
Table 1. Chemical-physical analysis, total protein, total lipid (g/100 g, FW), squalene, and cholesterol $(\mathrm{mg} / 100 \mathrm{~g}, \mathrm{FW})$ of fresh roe and bottarga from M. cephalus and L. ramada.

\begin{tabular}{cccccccc}
\hline Species & Sample & $\begin{array}{c}\text { Humidity (\%) } \\
\text { g/100 g FW }\end{array}$ & $\begin{array}{c}\text { Ash } \\
\text { g/100 g FW }\end{array}$ & $\begin{array}{c}\text { Total Protein } \\
\text { g/100 g FW }\end{array}$ & $\begin{array}{c}\text { Total Lipid } \\
\text { g/100 g FW }\end{array}$ & $\begin{array}{c}\text { Squalene } \\
\mathbf{~ m g / 1 0 0 ~ g ~}\end{array}$ & $\begin{array}{c}\text { Cholesterol } \\
\mathbf{~ m g / 1 0 0 ~ g ~}\end{array}$ \\
\hline \multirow{2}{*}{ L. ramada } & fresh & $47.6^{\mathrm{a}}$ & $5.9^{\mathrm{a}}$ & $24.5^{\mathrm{a}}$ & $2.7^{\mathrm{a}}$ & $11.3^{\mathrm{a}}$ & $474.7^{\mathrm{a}}$ \\
& bottarga & $13.6^{\mathrm{b}}$ & $8.6^{\mathrm{b}}$ & $24.7^{\mathrm{a}}$ & $11.3^{\mathrm{b}}$ & $24.6^{\mathrm{b}}$ & $621.0^{\mathrm{b}}$ \\
M. cephalus & fresh & $50.7^{\mathrm{a}}$ & $4.7^{\mathrm{a}}$ & $26.4^{\mathrm{a}}$ & $2.5^{\mathrm{a}}$ & $49.2^{\mathrm{c}}$ & $648.9^{\mathrm{b}}$ \\
& bottarga & $24.9^{\mathrm{c}}$ & $7.2^{\mathrm{b}}$ & $21.3^{\mathrm{a}}$ & $7.5^{\mathrm{c}}$ & $68.2^{\mathrm{d}}$ & $722.0^{\mathrm{c}}$ \\
\hline
\end{tabular}

In each column, means followed by a common letter are not significantly different by Fisher's least significant difference (LSD) procedure, $p \leq 0.05$.

\subsection{Metals and Metalloids}

The ICP-OES analytical method allowed the analysis of 22 metals and metalloids. Calibration curves showed $\mathrm{r}^{2}$ values ranging from $0.9967(\mathrm{~Pb})$ to $0.9997(\mathrm{Co})$ and that the limits of quantification of the method were adequate for this study (Table 2).

Table 2. Metal method parameters, limit of quantification (LOQ), correlation coefficient, and quantification wavelength $(\lambda)$.

\begin{tabular}{cccccc}
\hline Metal & $\boldsymbol{\lambda}$ & $\begin{array}{c}\text { LOQ } \\
(\mu \mathbf{g} / \mathbf{k g})\end{array}$ & Linear Regression Equation & $\mathbf{r}^{\mathbf{2}}$ \\
\hline $\mathrm{Al}$ & 396.15 & 0.05 & $\mathrm{y}=670.89 \mathrm{x}-45.48$ & 0.9978 \\
$\mathrm{As}$ & 193.69 & 0.05 & $\mathrm{y}=79.38 \mathrm{x}-10.14$ & 0.9991 \\
$\mathrm{~B}$ & 249.67 & 0.025 & $\mathrm{y}=5151.33 \mathrm{x}+789.8$ & 0.9995 \\
$\mathrm{Ba}$ & 455.40 & 0.05 & $\mathrm{y}=8035 \mathrm{x}-289.9$ & 0.9993 \\
$\mathrm{Be}$ & 313.10 & 0.001 & $\mathrm{y}=259,128 \mathrm{x}-6848$ & 0.9985 \\
$\mathrm{Cd}$ & 214.43 & 0.005 & $\mathrm{y}=4804 \mathrm{x}-3.55$ & 0.9995 \\
$\mathrm{Co}$ & 238.89 & 0.01 & $\mathrm{y}=6622.7 \mathrm{x}+58.6$ & 0.9997 \\
$\mathrm{Cr}$ & 205.56 & 0.025 & $\mathrm{y}=9908.7 \mathrm{x}+97.7$ & 0.9994 \\
$\mathrm{Cu}$ & 324.75 & 0.01 & $\mathrm{y}=17,117.2 \mathrm{x}-95.93$ & 0.9996 \\
$\mathrm{Fe}$ & 238.20 & 0.10 & $\mathrm{y}=3059.9 \mathrm{x}+80.8$ & 0.9992 \\
$\mathrm{Hg}$ & 194.16 & 0.10 & $\mathrm{y}=392.2 \mathrm{x}+11$ & 0.9994 \\
$\mathrm{Mn}$ & 257.61 & 0.005 & $\mathrm{y}=70,780.6 \mathrm{x}-8029$ & 0.9990 \\
$\mathrm{Mo}$ & 204.59 & 0.05 & $\mathrm{y}=604.4 \mathrm{x}-5.5$ & 0.9988 \\
$\mathrm{Ni}$ & 231.60 & 0.025 & $\mathrm{y}=1642.2 \mathrm{x}-22.3$ & 0.9986 \\
$\mathrm{~Pb}$ & 220.35 & 0.10 & $\mathrm{y}=297.3 \mathrm{x}-19.4$ & 0.9967 \\
$\mathrm{Sb}$ & 206.83 & 0.10 & $\mathrm{y}=49.7 \mathrm{x}-5.8$ & 0.9981 \\
$\mathrm{Sn}$ & 189.92 & 0.10 & $\mathrm{y}=74.3 \mathrm{x}-4.9$ & 0.9986 \\
$\mathrm{Sr}$ & 407.71 & 0.01 & $\mathrm{y}=829,945.3 \mathrm{x}+17943$ & 0.9984 \\
$\mathrm{Te}$ & 214.28 & 0.50 & $\mathrm{y}=106.6 \mathrm{x}-10.1$ & 0.9972 \\
$\mathrm{Ti}$ & 336.12 & 0.10 & $\mathrm{y}=14,275 \mathrm{x}+521.8$ & 0.9976 \\
$\mathrm{~V}$ & 292.40 & 0.005 & $\mathrm{y}=13,753.2 \mathrm{x}+231.2$ & 0.9996 \\
$\mathrm{Zn}$ & 213.85 & 0.10 & $\mathrm{y}=4785.9 \mathrm{x}-316$ & 0.9986 \\
\hline
\end{tabular}

Among the 22 metals and metalloids studied, only nine could be quantified in all matrices (Table 3). Despite the concentration factor, all metals showed lower concentration in the bottarga; the technological process of salting and removing the salt can affect the content of the metals, decreasing their overall content in the fish. $\mathrm{Pb}$ was detected only in low amounts in bottarga samples and was more abundant in M. cephalus. Zn was the most abundant both in fresh roe $(1.14$, and $0.73 \mu \mathrm{g} / \mathrm{g})$ and bottarga $(0.64$ and $0.44 \mu \mathrm{g} / \mathrm{g})$ in L. ramada and M. cephalus, respectively. Among all other metals, Fe and $\mathrm{Al}$ showed higher values in fresh and processed roe, with amounts slightly higher in M. cephalus. All metals showed higher levels in M. cephalus samples. This fact can be related to their feeding habits in seabed mud (Table 3). 
Table 3. Heavy metal composition $(\mu \mathrm{g} / \mathrm{kg} \mathrm{FW})$ of fresh roe and bottarga of M. cephalus and L. ramada collected from Sardinia lagoon.

\begin{tabular}{|c|c|c|c|c|c|c|}
\hline \multirow[b]{2}{*}{ Metal } & \multicolumn{3}{|c|}{ Liza ramada } & \multicolumn{3}{|c|}{ Mugil cephalus } \\
\hline & Fresh & Bottarga & Decrease & Fresh & Bottarga & Decrease \\
\hline & \multicolumn{2}{|c|}{$\begin{array}{c}\mu \mathrm{g} / \mathrm{kg} \\
\{\backslash \text { displaystyle } \backslash \text { sigma }\}\end{array}$} & $\%$ & \multicolumn{2}{|c|}{$\begin{array}{c}\mu \mathrm{g} / \mathrm{kg} \\
\{\backslash \text { displaystyle } \backslash \text { sigma\} }\end{array}$} & $\begin{array}{c}\% \\
\{\backslash \text { displaystyle } \backslash \text { sigma }\}\end{array}$ \\
\hline $\mathrm{Al}$ & $88.2^{a}$ & $26.2^{b}$ & 70.3 & $121.4^{\mathrm{a}}$ & $27.9^{b}$ & 77.0 \\
\hline As & $<\mathrm{LOQ}$ & $<\mathrm{LOQ}$ & & $<\mathrm{LOQ}$ & $<\mathrm{LOQ}$ & \\
\hline B & $47.1^{\mathrm{a}}$ & $14.9^{\widehat{b}}$ & 68.4 & $67.5^{a}$ & $19.3^{\widehat{b}}$ & 71.4 \\
\hline $\mathrm{Ba}$ & $5.4^{\mathrm{a}}$ & $1.8^{\mathrm{b}}$ & 66.7 & $4.8^{\mathrm{a}}$ & $1.8^{\mathrm{b}}$ & 62.5 \\
\hline $\mathrm{Be}$ & $<\mathrm{LOQ}$ & $<\mathrm{LOQ}$ & & $<\mathrm{LOQ}$ & $<\mathrm{LOQ}$ & \\
\hline $\mathrm{Cd}$ & $<\mathrm{LOQ}$ & $<\mathrm{LOQ}$ & & $<$ LOQ & $<$ LOQ & \\
\hline $\mathrm{Co}$ & $<\mathrm{LOQ}$ & $<\mathrm{LOQ}$ & & $<\mathrm{LOQ}$ & $<\mathrm{LOQ}$ & \\
\hline $\mathrm{Cr}$ & $<\mathrm{LOQ}$ & $<\mathrm{LOQ}$ & & $<$ LOQ & $<\mathrm{LOQ}$ & \\
\hline $\mathrm{Cu}$ & $17.3^{\mathrm{c}}$ & $10.9^{\mathrm{c}}$ & 37.0 & $43.6^{a}$ & $28.3^{\widehat{b}}$ & 35.1 \\
\hline $\mathrm{Fe}$ & $206.9^{b}$ & 98.2 & 52.5 & $358.4^{\mathrm{a}}$ & $159.3^{b}$ & 55.6 \\
\hline $\mathrm{Hg}$ & $<\mathrm{LOQ}$ & $<\mathrm{LOQ}$ & & $<$ LOQ & $<\mathrm{LOQ}$ & \\
\hline $\mathrm{Mn}$ & $11.4^{\mathrm{a}}$ & $4.6^{\mathrm{c}}$ & 59.6 & $18.4^{\mathrm{a}}$ & $7.2^{\mathrm{b}}$ & 60.9 \\
\hline Mo & $<\mathrm{LOQ}$ & $<\mathrm{LOQ}$ & & $<\mathrm{LOQ}$ & $<\mathrm{LOQ}$ & \\
\hline $\mathrm{Ni}$ & $4.1^{\mathrm{b}}$ & $2.6^{\mathrm{c}}$ & 36.6 & $7.2^{\mathrm{a}}$ & $4.6^{\mathrm{b}}$ & 36.1 \\
\hline $\mathrm{Pb}$ & $<\mathrm{LOQ}$ & $8.4^{\mathrm{b}}$ & & $<\mathrm{LOQ}$ & $14.1^{\mathrm{a}}$ & \\
\hline $\mathrm{Sb}$ & $<$ LOQ & $<\mathrm{LOQ}$ & & $<$ LOQ & $<$ LOQ & \\
\hline Sn & $<\mathrm{LOQ}$ & $<\mathrm{LOQ}$ & & $<\mathrm{LOQ}$ & $<\mathrm{LOQ}$ & \\
\hline $\mathrm{Sr}$ & $5.3^{c}$ & $1.9^{\mathrm{b}}$ & 64.2 & $7.4^{\mathrm{a}}$ & $2.9^{\mathrm{b}}$ & 60.8 \\
\hline $\mathrm{Te}$ & $<$ LOQ & $<$ LOQ & & $<$ LOQ & $<$ LOQ & \\
\hline $\mathrm{Ti}$ & $<\mathrm{LOQ}$ & $<\mathrm{LOQ}$ & & $<$ LOQ & $<$ LOQ & \\
\hline $\mathrm{V}$ & $<\mathrm{LOQ}$ & $<\mathrm{LOQ}$ & & $<\mathrm{LOQ}$ & $<\mathrm{LOQ}$ & \\
\hline $\mathrm{Zn}$ & $729.2^{\mathrm{b}}$ & $441.0^{\mathrm{c}}$ & 39.5 & $1143.5^{\mathrm{a}}$ & $635.9^{\widehat{b}}$ & 44.4 \\
\hline
\end{tabular}

In each row, means followed by a common letter are not significantly different by Fisher's least significant difference (LSD) procedure, $p \leq 0.05$.

\subsection{Proteins and Amino Acids}

Total protein content ranged from 21.31 to $26.43 \mathrm{~g} / 100 \mathrm{~g}$, showing statistically even values in both species, and this did not change after processing (Table 1 ).

The analysis carried out on the free amino acids allowed the determination of 11 compounds among the 17 investigated, the most concentrated being glutamine in the fresh roe of both species. Within the same species, there were significant variations in fresh roe vs. bottarga, except for glycine and proline in L. ramada, and isoleucine, proline, phenylalanine, and lysine in M. cephalus. Glutamine, phenylalanine, and lysine had significantly lower values in the bottarga of $L$. ramada, while there was a lower value of glutamine in those of M. cephalus. Proline showed even amounts in all samples (Table 4).

Table 4. Free amino acid composition ( $\% \pm$ RSD) of fresh roe and bottarga from L. ramada and M. cephalus samples.

\begin{tabular}{ccccc}
\hline Aminoacid & \multicolumn{2}{c}{ Liza ramada } & \multicolumn{2}{c}{ Mugil cephalus } \\
& Fresh & Bottarga & Fresh & Bottarga \\
\hline Alanine & $8.8^{\mathrm{a}^{*}}$ & $13.1^{\mathrm{b}}$ & $7.3^{\mathrm{a}}$ & $11.4^{\mathrm{b}}$ \\
Glycine & $7.2^{\mathrm{a}}$ & $8.4^{\mathrm{a}}$ & $6.6^{\mathrm{a}}$ & $12.8^{\mathrm{b}}$ \\
Valine & $6.3^{\mathrm{a}}$ & $11.2^{\mathrm{b}}$ & $5.6^{\mathrm{a}}$ & $9.4^{\mathrm{b}}$ \\
Isoleucine & $5.1^{\mathrm{a}}$ & $8.3^{\mathrm{b}}$ & $4.3^{\mathrm{a}}$ & $6.6^{\mathrm{a}}$ \\
Proline & $5.2^{\mathrm{a}}$ & $7.8^{\mathrm{a}}$ & $4.7^{\mathrm{a}}$ & $5.1^{\mathrm{a}}$ \\
Serine & $7.4^{\mathrm{a}}$ & $16.3^{\mathrm{b}}$ & $9.3^{\mathrm{a}}$ & $14.7^{\mathrm{b}}$ \\
\hline
\end{tabular}


Table 4. Cont.

\begin{tabular}{|c|c|c|c|c|}
\hline \multirow[t]{2}{*}{ Aminoacid } & \multicolumn{2}{|c|}{ Liza ramada } & \multicolumn{2}{|c|}{ Mugil cephalus } \\
\hline & Fresh & Bottarga & Fresh & Bottarga \\
\hline Threonine $\mathrm{e}^{\mathrm{e}}$ & $6.4^{\mathrm{a}}$ & $11.7^{\mathrm{b}}$ & $6.3^{a}$ & $10.2^{b}$ \\
\hline Glutamine & $25.6^{\mathrm{a}}$ & $13.6^{b}$ & $20.1^{a}$ & $12.3^{b}$ \\
\hline Phenylalanine ${ }^{\mathrm{e}}$ & $9.1^{\mathrm{a}}$ & $5.2^{b}$ & $7.5^{\mathrm{a}}$ & $6.3^{\mathrm{a}}$ \\
\hline Lysine $\mathrm{e}^{\mathrm{e}}$ & $6.6^{\mathrm{a}}$ & $4.0^{\mathrm{b}}$ & $6.2^{\mathrm{a}}$ & $7.1^{\mathrm{a}}$ \\
\hline Tyrosine $^{\mathrm{e}}$ & & $0.2^{\mathrm{a}}$ & & $1.2^{\mathrm{b}}$ \\
\hline TAA & $87.70 \pm 3.31$ & $99.80 \pm 0.02$ & $47.48 \pm 0.54$ & $38.78 \pm 3.64$ \\
\hline EAA & $33.47 \pm 2.35$ & $40.46 \pm 1.01$ & $17.80 \pm 0.11$ & $17.11 \pm 2.30$ \\
\hline EAA/TAA \% & $38.17 \pm 0.97$ & $40.54 \pm 0.99$ & $37.24 \pm 0.66$ & $44.14 \pm 3.00$ \\
\hline
\end{tabular}

* In each raw grouping, means followed by a common letter are not significantly different by Fisher's least significant difference (LSD) procedure, $p \leq 0.05$. ${ }^{\mathrm{e}}$ essential amino acids.

\subsection{Lipid Fraction}

Total lipids were even in the fresh samples of M. cephalus and L. ramada, accounting for 2.46 and $2.76 \mathrm{~g} / 100 \mathrm{~g}$, respectively; after processing, they increased to 7.46 and $11.31 \mathrm{~g} / 100 \mathrm{~g}(\mathrm{FW})$, respectively. The same trend was shown by squalene and cholesterol, which showed higher values in the samples of bottarga. M. cephalus showed higher values of cholesterol and squalene than those detected in L. ramada (Table 1).

A total of 51 fatty acids were identified in the gonads of both fish. In the fresh gonads of $M$. cephalus, SAFAs represented 20.4\%, MUFAs 54.4\%, and PUFAs 24.7\%. After processing into bottarga, total MUFAs remained unchanged, while SAFAs decreased and PUFAs increased (Tables 5 and 6).

Table 5. Fatty acid composition (\%) of fresh roe and bottarga of M. cephalus and L. ramada collected from Sardinia lagoon.

\begin{tabular}{ccccc}
\hline Fatty Acid & \multicolumn{2}{c}{ Liza ramada } & \multicolumn{2}{c}{ Mugil cephalus } \\
& Fresh & Bottarga & Fresh & Bottarga \\
\hline anteiso C14 & $0.03^{\mathrm{a}^{\mathrm{a}}}$ & $0.04^{\mathrm{a}}$ & $0.03^{\mathrm{a}}$ & $0.03^{\mathrm{a}}$ \\
C14:0 & $3.55^{\mathrm{b}}$ & $1.99^{\mathrm{a}}$ & $2.73^{\mathrm{b}}$ & $1.60^{\mathrm{a}}$ \\
anteiso C15:0 & $0.18^{\mathrm{b}}$ & $0.08^{\mathrm{a}}$ & $0.14^{\mathrm{b}}$ & $0.09^{\mathrm{a}}$ \\
C15:0 + isomer & $2.04^{\mathrm{c}}$ & $1.37^{\mathrm{a}}$ & $1.64^{\mathrm{b}}$ & $1.50^{\mathrm{b}}$ \\
anteiso C16 & $1.28^{\mathrm{b}}$ & $1.93^{\mathrm{c}}$ & $1.83^{\mathrm{c}}$ & $0.04^{\mathrm{a}}$ \\
C16:0 & $12.60^{\mathrm{b}}$ & $12.84^{\mathrm{b}}$ & $9.60^{\mathrm{a}}$ & $9.16^{\mathrm{a}}$ \\
C17:0 & $0.42^{\mathrm{b}}$ & $0.74^{\mathrm{c}}$ & $0.25^{\mathrm{a}}$ & $0.57^{\mathrm{b}}$ \\
C18:0 & $1.76^{\mathrm{b}}$ & $1.70^{\mathrm{b}}$ & $1.01^{\mathrm{a}}$ & $1.46^{\mathrm{b}}$ \\
anteiso C19 & $0.05^{\mathrm{a}}$ & $0.04^{\mathrm{a}}$ & $0.06^{\mathrm{a}}$ & 0.05 \\
C20:0 & $0.09^{\mathrm{a}}$ & $0.14^{\mathrm{b}}$ & & \\
\hline C14:1+isomer & $0.11^{\mathrm{a}}$ & $0.03^{\mathrm{a}}$ & $0.38^{\mathrm{b}}$ & $0.08^{\mathrm{a}}$ \\
C15:1 + isomer & $0.72^{\mathrm{b}}$ & $0.33^{\mathrm{a}}$ & $0.77^{\mathrm{b}}$ & $0.51^{\mathrm{a}}$ \\
C16:1 + isomer & $30.45^{\mathrm{b}}$ & $27.18^{\mathrm{a}}$ & $30.09^{\mathrm{b}}$ & $24.85^{\mathrm{a}}$ \\
C16:2 & $0.32^{\mathrm{a}}$ & $0.42^{\mathrm{a}}$ & $0.40^{\mathrm{a}}$ & \\
C16:1 n9 7 methyl & $0.15^{\mathrm{a}}$ & $0.22^{\mathrm{b}}$ & $0.12^{\mathrm{a}}$ & $0.13^{\mathrm{a}}$ \\
C17:1 & $1.68^{\mathrm{a}}$ & $2.81^{\mathrm{b}}$ & $1.57^{\mathrm{a}}$ & $3.00^{\mathrm{b}}$ \\
C18:1c & $16.32^{\mathrm{b}}$ & $12.74^{\mathrm{a}}$ & $16.06^{\mathrm{b}}$ & $13.01^{\mathrm{a}}$ \\
C18:1 $\Delta 11$ & $5.30^{\mathrm{a}}$ & $10.33^{\mathrm{b}}$ & $5.29^{\mathrm{a}}$ & $11.42^{\mathrm{b}}$ \\
C20:1 & $0.13^{\mathrm{a}}$ & & $0.13^{\mathrm{a}}$ & $0.56^{\mathrm{b}}$ \\
C20:1n7 & $0.13^{\mathrm{a}}$ & $0.32^{\mathrm{b}}$ & $0.22^{\mathrm{b}}$ & $0.10^{\mathrm{a}}$ \\
C20:1n4 & $0.23^{\mathrm{b}}$ & $0.17^{\mathrm{a}}$ & $0.26^{\mathrm{b}}$ & \\
\hline
\end{tabular}


Table 5. Cont.

\begin{tabular}{|c|c|c|c|c|}
\hline \multirow[t]{2}{*}{ Fatty Acid } & \multicolumn{2}{|c|}{ Liza ramada } & \multicolumn{2}{|c|}{ Mugil cephalus } \\
\hline & Fresh & Bottarga & Fresh & Bottarga \\
\hline C17:2 & $1.36^{\mathrm{b}}$ & $0.80^{\mathrm{a}}$ & $1.18^{b}$ & $2.68^{c}$ \\
\hline C18:2 & $0.55^{\mathrm{a}}$ & $2.65^{c}$ & & $1.75^{b}$ \\
\hline $\mathrm{C} 18: 2 \mathrm{n} 6 \mathrm{t}$ & $0.17^{\mathrm{a}}$ & $0.42^{b}$ & $1.44^{\mathrm{c}}$ & $1.76^{\mathrm{c}}$ \\
\hline C18:2 n6c & $1.17^{\mathrm{c}}$ & $0.75^{b}$ & $0.20^{\mathrm{a}}$ & $1.34^{\mathrm{c}}$ \\
\hline C18:2 & $0.66^{b}$ & $0.52^{b}$ & $1.27^{\mathrm{c}}$ & $0.17^{\mathrm{a}}$ \\
\hline C18:3 & $0.22^{a}$ & $0.32^{\mathrm{a}}$ & $0.70^{b}$ & $0.26^{\mathrm{a}}$ \\
\hline$\gamma \mathrm{C} 18: 3 \mathrm{n} 6$ & $0.34^{\mathrm{a}}$ & $0.47^{a b}$ & $0.20^{\mathrm{a}}$ & $0.53^{b}$ \\
\hline$\alpha \mathrm{C} 18: 3$ & $1.16^{\mathrm{c}}$ & $0.81^{b c}$ & $0.43^{\mathrm{a}}$ & $0.55^{\mathrm{b}}$ \\
\hline unknow & $1.98^{\mathrm{b}}$ & $1.74^{\mathrm{a}}$ & $2.03^{b}$ & \\
\hline $\mathrm{C} 18: 4 \mathrm{n} 3$ & $1.20^{b}$ & $0.60^{\mathrm{a}}$ & $3.94^{c}$ & $4.28^{c}$ \\
\hline CLA C18:2 & $1.21^{\mathrm{b}}$ & $0.69^{a}$ & $1.11^{\mathrm{b}}$ & $1.61^{b}$ \\
\hline CLA C18:2 & $0.80^{\mathrm{a}}$ & $2.59^{c}$ & $1.71^{\mathrm{b}}$ & $2.57^{\mathrm{c}}$ \\
\hline C20:2 + isomer & $0.17^{\mathrm{a}}$ & $0.23^{b}$ & $1.56^{\mathrm{b}}$ & $0.15^{\mathrm{a}}$ \\
\hline C20:3 & $0.21^{\mathrm{a}}$ & $2.36^{b}$ & $0.14^{\mathrm{a}}$ & $0.25^{\mathrm{a}}$ \\
\hline C20:4 & $0.44^{\mathrm{a}}$ & $1.06^{b}$ & $0.45^{\mathrm{a}}$ & $1.35^{\mathrm{b}}$ \\
\hline C20:3n3 (11-14-17) & $0.07^{\mathrm{a}}$ & $0.10^{\mathrm{a}}$ & $0.08^{a}$ & $0.13^{a}$ \\
\hline $\mathrm{C} 20: 4 \mathrm{n} 3$ & $0.74^{\mathrm{a}}$ & $2.77^{b}$ & $0.90^{\mathrm{a}}$ & $0.95^{\mathrm{a}}$ \\
\hline C20:5 EPA & $3.00^{b}$ & $1.41^{\mathrm{a}}$ & $3.71^{b}$ & $2.19^{a b}$ \\
\hline C20:3n9 & $0.11^{\mathrm{a}}$ & & $0.07^{\mathrm{a}}$ & \\
\hline C21:4 & $0.36^{\mathrm{b}}$ & $0.17^{\mathrm{a}}$ & $0.42^{b}$ & $0.12^{\mathrm{a}}$ \\
\hline $\mathrm{C} 21: 5 \mathrm{n} 3$ & $0.36^{b}$ & $0.15^{\mathrm{a}}$ & $0.23^{a}$ & $0.31^{\mathrm{ab}}$ \\
\hline C22:5 & $1.83^{\mathrm{a}}$ & $2.12^{b}$ & $1.92^{\mathrm{ab}}$ & \\
\hline C22:6 DHA & $4.37^{b}$ & $2.00^{\mathrm{a}}$ & $3.50^{b}$ & \\
\hline
\end{tabular}

* In each raw grouping, means followed by a common letter are not significantly different by Fisher's least significant difference (LSD) procedure, $p \leq 0.05$.

Table 6. Fatty acid composition (\%) of fresh roe and bottarga of M. cephalus and L. ramada collected from Sardinia lagoon.

\begin{tabular}{|c|c|c|c|c|}
\hline & \multicolumn{2}{|c|}{ Liza ramada } & \multicolumn{2}{|c|}{ Mugil cephalus } \\
\hline & Fresh & Bottarga & Fresh & Bottarga \\
\hline$\sum$ saturated & $21.98^{b}$ & $20.84^{b}$ & $17.34^{\mathrm{ab}}$ & $14.58^{a}$ \\
\hline$\Sigma$ monounsaturated & $55.55^{\mathrm{a}}$ & $54.44^{\mathrm{a}}$ & $54.80^{\mathrm{a}}$ & $56.07^{a}$ \\
\hline ¿polyunsaturated & $22.47^{\mathrm{a}}$ & $24.72^{a b}$ & $26.21 \mathrm{bc}$ & $29.36^{c}$ \\
\hline PUFA/SAFA & $1.02^{\mathrm{a}}$ & 1.59 & $1.19^{\mathrm{a}}$ & 2.03 \\
\hline$\sum \omega 3(\%)$ & $14.01^{\mathrm{c}}$ & $14.24^{c}$ & $9.95^{b}$ & $6.44^{\mathrm{a}}$ \\
\hline$\Sigma \omega 6(\%)$ & $2.17^{\mathrm{a}}$ & $3.28^{a}$ & $8.56^{c}$ & $6.07^{b}$ \\
\hline$\omega 3 / \omega 6$ & $6.44^{\mathrm{b}}$ & $4.41^{b}$ & $1.17^{\mathrm{a}}$ & $1.12^{\mathrm{a}}$ \\
\hline
\end{tabular}

In each raw grouping, means followed by a common letter are not significantly different by Fisher's least significant difference (LSD) procedure, $p \leq 0.05$.

The same behavior was found in the samples of L ramada. C16:1 mainly represented MUFAs, followed by $\mathrm{C} 18: 1 \triangle 9 \mathrm{c}$ and $\mathrm{C} 18: 1 \Delta 11$. C16:0 (between $10 \%$ and $15 \%$ ) and $\mathrm{C} 14: 0$ (between $2 \%$ and $4 \%$ ) were the SAFAs most represented. Non-negligible concentrations of C15:0 and C18:0 (about 2\%) were detected. C17:0 has been identified as a typical chemical indicator of the lipid fraction of M. cephalus, according to Pigott et al. (2003) [28], and it was also found in L. ramada (Table 5).

PUFAs were represented by DHA (C22:6 n6), EPA (C20:5 n3), and C18:2 conjugated linoleic acid (CLA) isomers. C18:2 and fatty acids with 3 and 4 double bonds increased in bottarga, while EPA and DHA decreased. Short-chain length acids (C14 and C15) decreased both in SAFAs and MUFAs, and an unusual inversion of the oleic-vaccenic ratio was detected in bottarga. Fresh gonads of L ramada showed an amount of SAFAs of $21.9 \pm 0.5 \%$, MUFAs of $55.2 \pm 1.8 \%$, and PUFAs of $22.4 \pm 5.3 \%$, with 
a behavior similar to M. cephalus after processing (Table 5). Unsaturated fatty acids of the $\omega 3$ series accounted for $14.01 \%$ and $9.95 \%$ in fresh roe and $14.24 \%$ and $6.44 \%$ in bottarga for L. ramada and M. cephalus, respectively (Table 6). On the other hand, $\omega 6$ was $2.17 \%$ and $8.56 \%$ in fresh samples and $3.28 \%$ and $6.07 \%$ after processing, respectively (Table 6). The $\omega 3 / \omega 6$ ratio was 4.41 and 1.12, respectively, showing a net increase of the $\omega 6$ fraction in L. ramada bottarga (Table 6).

\subsection{Geosmine and 2-Methyl Isoborneol}

No traces of geosmine and 2-methylisoborneol were found in fresh roe and bottarga in both mullets. The lagoon of Cabras has an elevate ecological resilience to adverse environmental conditions as a potential source of the growth of algae and cyanobacteria. The stability of environmental conditions appears essential in controlling Cyanophyceae development in many cases [29-32].

\subsection{Multivariate Analysis}

Principal component analysis (PCA) of all data from the analysis reported showed four clustering groups differentiating within the samples and within the species on the PC1 and PC2 axes (Figure 1).

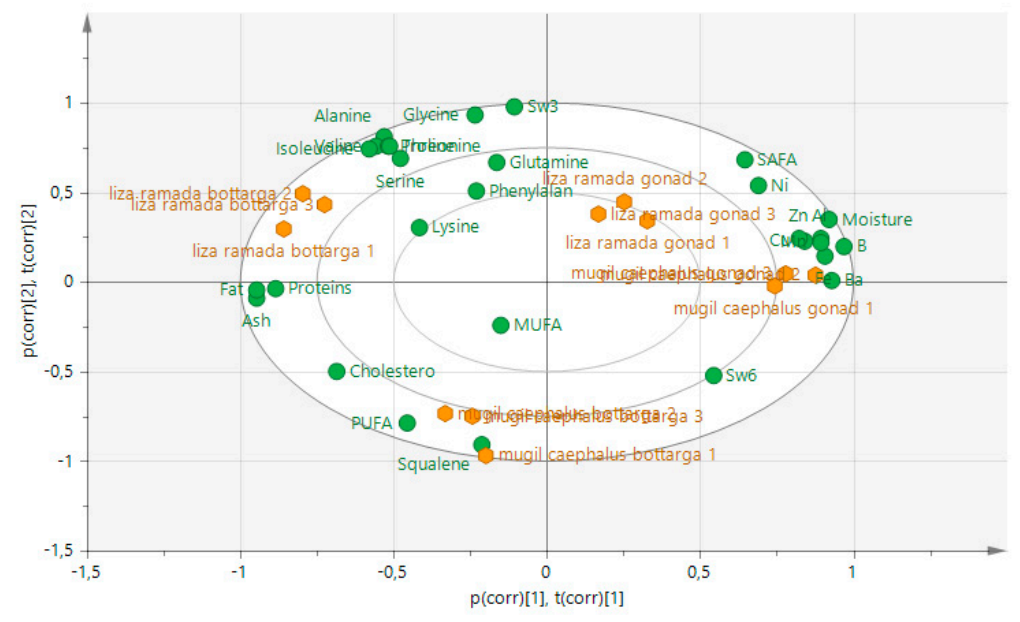

Figure 1. Principal component analysis (PCA) score scatter biplot of fresh gonads and bottarga from the two mullet species.

A biplot approach was taken to better emphasize the similarities or differences among the groups. L. ramada gonads had higher levels than the corresponding bottarga of SAFAs, metals $(\mathrm{Cu}, \mathrm{Ni}, \mathrm{Zn}, \mathrm{Mn}$, $\mathrm{Al}, \mathrm{Fe}$, and $\mathrm{B}$ ), and the amino acids phenylalanine, glutamine, and lysine. In contrast, bottarga had higher values of the other amino acids, total lipid, squalene, cholesterol, PUFAs, and, among these, of $\omega 6$ (Figure 2A). M. caephalus gonads were rich in $\omega 3, \omega 6$, and SAFAs and the amino acids isoleucine, proline, glycine, valine, alanine, serine, and threonine. At the same time, the corresponding bottarga had higher concentrations of total proteins, total lipid, squalene, cholesterol, PUFAs, and the amino acid glutamine (Figure 2B).

Squalene, cholesterol, PUFA $\omega 6$, and Fe on the right side of the PC1 axis and isoleucine proline, valine, alanine phenylalanine, glutamine, glycine, and $\omega 3$, together with total lipid on the left side of the PC1 axis, allowed us to discriminate M. caephalus from L. ramada both in bottarga and gonads (Figure 3A,B). 


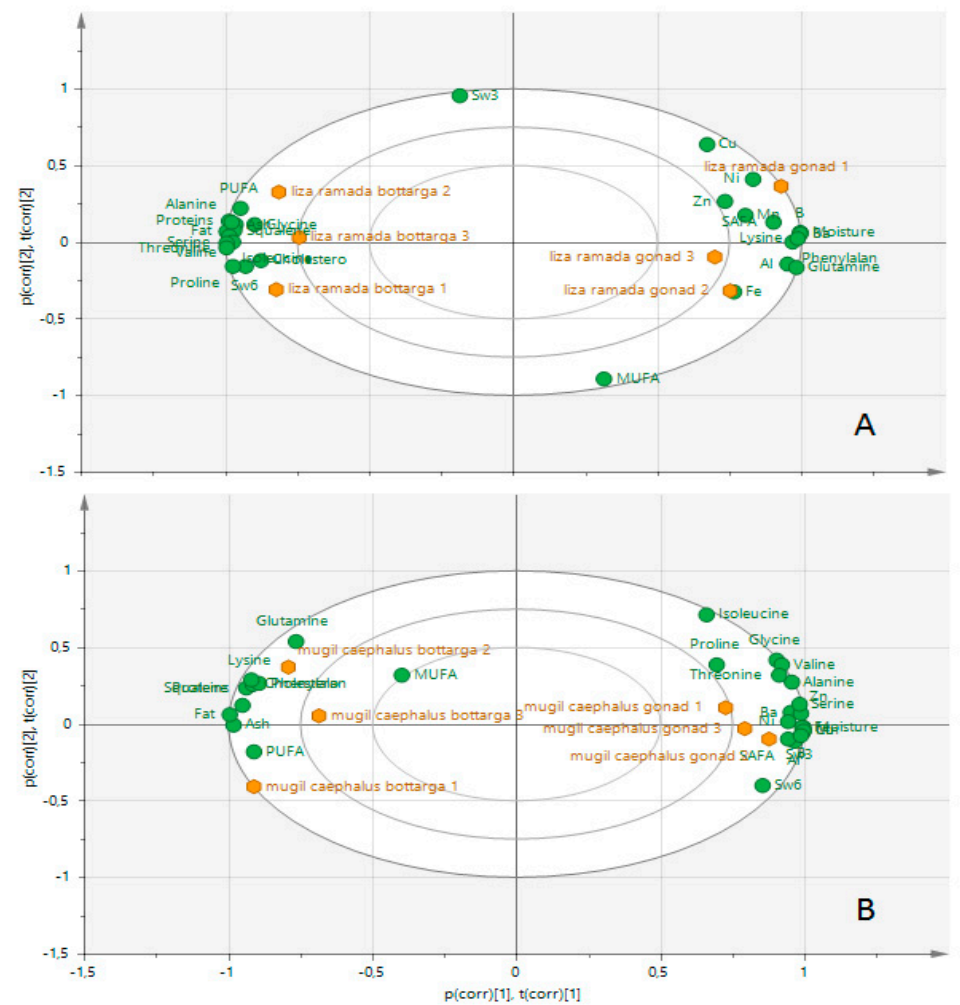

Figure 2. Biplot from PCA analysis of the samples of bottarga vs. fresh roe from Liza ramada (A), and Mugil cephalus (B).
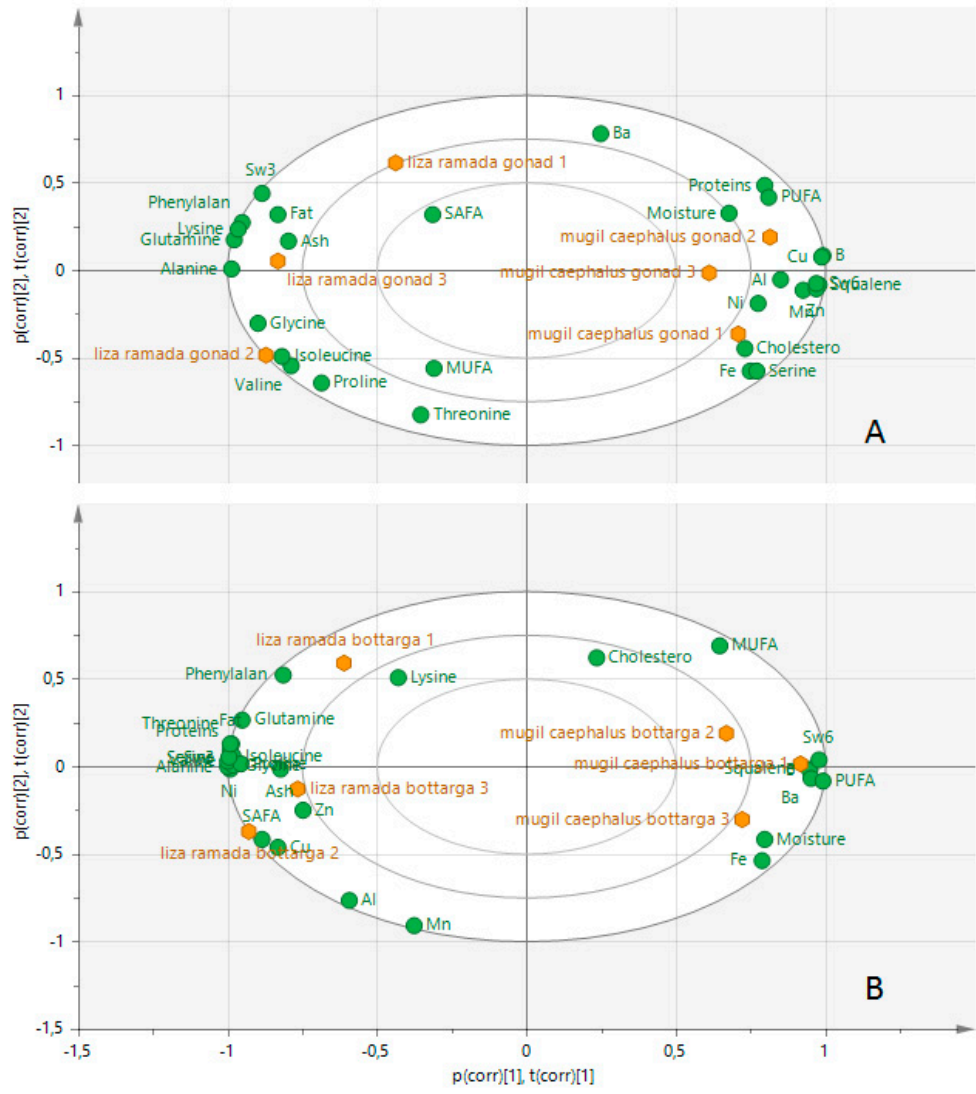

Figure 3. Biplot from PCA analysis of the samples of fresh roe (gonads) (A), and bottarga (B) from Liza ramada vs. Mugil cephalus. 


\section{Discussion}

Food processing leads to a final product that is entirely different from the starting raw material, depending on the impact on the biochemical composition. Salting out represents one of the oldest techniques for food, especially fish, preservation and increasing shelf life [33].

In this paper, the entire process of salting has been optimized in terms of time, temperature, and moisture. The rate time/material for the salting step was set at $1 \mathrm{~h} / 200 \mathrm{~g}$, ensuring a moderate dehydrating effect and avoiding an excessive nonhealthy increase of the $\mathrm{NaCl}$ content in the bottarga. Celik et al. [16] reported a rate of $2.5 \mathrm{~h} / 200 \mathrm{~g}$ and an increase in minerals related to $\mathrm{NaCl}$, like those reported by Barra et al. [12], almost two times the values reported in this paper. The pressing step of one day was adequate to give the product a shape and further reduced moisture. Organoleptic acceptance of a panel of qualified consumers set the ideal moisture content for an appropriate final bottarga consistency at $30 \%$; therefore, the drying days were adapted to the gonad weight.

The data reported on the proximate composition showed similar values with those reported previously by Celik et al. (2012) [16] and Caredda et al. (2018) [17]. Moreover, our data showed similar proximate values for fresh and processed gonads. On the other hand, the values of moisture reported for bottarga were lower than those detected by Lu et al. (1979) [34] and Kalogeropoulos et al. (2008) [35]. This fact can be explained by considering the differences in the salting step carried out under brine $(15 \% \mathrm{NaCl})$ by Lu et al. and the coverage with beeswax following Greek-style processing by Kalogeropulos et al. Both methods reduced water evaporation, increasing moisture in the bottarga.

Most papers have reported data on samples that were already processed or compared fresh roe versus processed samples from different fish [12,17]. Our samples followed the entire production chain, being samples from the same fish, analyzed before and after processing. This approach allowed a better understanding of the effect of the technological process on biochemical composition.

Total lipids showed higher values in bottarga than in the fresh roe but lower values than those reported by other authors, according to Kalogeropulos et al. [35].

Fatty acid composition of bottarga follows the series MUFA > PUFA > SAFA, according to literature data $[6,35,36]$; however, the present paper detected a higher level of MUFAs and a lower level of SAFAs. The final ratio of PUFA/SAFA was $40 \%$ higher than data from previous studies on roe processed in Sardinia but from different origins.

Moreover, unsaturated fatty acid content was higher than those reported for caviar $(4.8 \%)$ and Morone saxatilis eggs (1.3\%) [37,38].

No data are available on the changes in fatty acid and free amino acid composition during processing. Our data showed an increase in PUFAs (C18:2 family) and a decrease in SAFAs (C15:0), with a higher rate of PUFA/SAFA in bottarga then in fresh roes.

Salting can have a substantial effect on protein structure and degradation [39]. Free amino acids are produced by the hydrolysis of proteins, influencing the flavor characteristics of the processed food. The analysis of the free amino acid fraction showed higher values of essential amino acid/total amino acid ratio (EAA/TAA) in bottarga vs. fresh gonads. Among the 11 free amino acids detected, the analysis showed a general increase of all compounds in bottarga except for glutamine, which decreased in all samples.

The data of metals and metalloids showed that the salting step significantly affected their concentration. Decreasing rates ranged from $35.1 \%(\mathrm{Cu})$ to $77.0 \%(\mathrm{Al})$, assuming a possible removal effect associated with water extraction by the external salt. Amir et al. (2018) reported the performance of acidic and alkaline solutions and biological extracts in reducing heavy metal content from spinach after dip washing [40].

Multivariate analysis is a powerful tool for sample discrimination, and it has been used to differentiate among bottarga of different origins [12]. In this paper, PCA allowed us to evaluate the significance of the biochemical changes among fresh roe and bottarga and between L. ramada and M. cephalus composition. 
The biochemical analysis allowed us to perform a nutritional evaluation of the bottarga of the two fish species. Fish roe consumption is diffused in the world; however, different considerations on the nonhealthy effect of some chemical components have been made.

Cholesterol quantitation showed different results, varying from 290 to $590 \mathrm{mg} / 100 \mathrm{~g}$ [41]. Considering the levels of cholesterol found in this paper and an FDI of bottarga around $10 \mathrm{~g}$, the overall intake could reach values of cholesterol between 47.5 and $72.2 \mathrm{mg}$, which is almost three times lower than an egg of $50 \mathrm{~g}$ (180 $\mathrm{mg}$ of cholesterol). L. ramada processed roe showed levels of cholesterol lower than those reported by Rosa et al. [6] and similar to those reported by Kalogeropoulos [35] and Barra [12].

The high levels of squalene and $\omega 3$ fatty acid will provide a relevant health profile. A high PUFA content is related to a high nutritional value of food [28,42]; moreover, recent research pointed out the health benefits of $\omega 3$ as the precursor of bioactive epoxides. These $\omega 3$ endocannabinoid epoxides interact with THC receptors, playing crucial roles in modulating neuroinflammation and cerebrovascular disease [43].

Amino acids are essential components of the human diet for body health; glycine, serine, alanine, proline, and other amino acids are involved in tissue regrowth and healing. Glutamine is necessary for cell proliferation. Essential amino acids are not produced in human bodies but are assimilated from food. Among the eight amino acids generally regarded as essential for humans, in our samples, we found phenylalanine, valine, threonine, isoleucine, leucine, and lysine.

The two species of mullets result in good sources of amino acids, with values according to WHO/FAO/UNU indications for human nutrition [44].

\section{Conclusions}

Bottarga represents a highly priced delicacy, and its consumption is usually limited to appetizers, sashimi, or as a sauce for pasta.

This paper has reported the influence of industrial processing on the biochemical composition of fresh roe from two mugilid species, Liza ramada and Mugil cephalus. Eight different chemical analyses were performed for the characterization of the bottarga produced from the fresh roe. The processing step affected the quality and composition of the bottarga, which showed an attractive nutritional value due to its lipidic profile in both fatty acid and squalene, low levels of cholesterol, and an increased EAA/TAA ratio. PCA analysis showed clear discrimination among the two species in both fresh roe and bottarga. L. ramada showed a better ratio of $\omega 3 / \omega 6$ but lower values of squalene and cholesterol. Finally, the paper reported, for the first time, a comprehensive evaluation of metal and metalloid composition.

In addition to nutritional benefits for the consumer, the findings of the paper also have a significant impact on the producers of processed roe. The leading enterprises have a codified and, sometimes, patented processing method to obtain homogeneous products with unchanging organoleptic characteristics. Moreover, small and local producers make use of empirical and traditional methodologies, leading to different products among the same batch and between batches. Thus, the process set in this paper may represent an easy-to-use and reliable tool to obtain a final bottarga, with both a reproducible biochemical composition and organoleptic characteristics.

Author Contributions: Conceptualization, A.A. (Alberto Angioni) and P.A.; methodology, A.A. (Alessandro Atzei); validation, F.C. and G.S.; formal analysis, G.S., F.C., and A.A. (Alessandro Atzei); sample collection A.C., A.G., and V.P.; writing-review and editing, A.A. (Alberto Angioni) and F.C. All authors have read and agreed to the published version of the manuscript.

Funding: This research received no external funding.

Acknowledgments: The paper was made with the contribution of researchers from the Italian Society of Food Chemistry (Itachemfood).

Conflicts of Interest: The authors declare no conflict of interest. 


\section{References}

1. Crosetti, D.; Blaber, S.J.M. (Eds.) Biology, Ecology and Culture of Grey Mullets (Mugilidae); CRC Press: Boca Raton, FL, USA, 2016.

2. Saleh, M.A. Cultured Aquatic Species Information Programme; Mugil cephalus; FAO Fisheries and Aquaculture Department: Rome, Italy, 2006.

3. Saleh, M. Capture-based aquaculture of mullets in Egypt. In Capture-Based Aquaculture, Technical Paper; A. Lovatelli, A., Holthus, P.F., Eds.; FAO Fisheries: Rome, Italy, 2008.

4. Thomson, J.M. Mugelidae. In Check List of the Fishes of the Eastern Tropical Atlantic; Quero, J.C., Hureau, J.C., Post, C.A., Saldanha, L., Eds.; UNESCO: Paris, France, 1990.

5. Bledsoe, G.E.; Bledsoe, C.D.; Rasco, B. Caviars and fish roe products. Crit. Rev. Food Sci. Nutr. 2003, 43, 317-356. [CrossRef] [PubMed]

6. Rosa, A.; Atzeri, A.; Deiana, M.; Melis, M.P.; Ancani, A.; Loru, D.; Cabboi, B.; Dessì, M.A. Mullet bottarga as functional ingredient. Aliment. Funz. 2014, 6, 2-11.

7. Brownlie, I. The Rule of Law in International Affairs: International Law at the Fiftieth Anniversary of the United Nations; Martinus Nijhoff Publishers: Leiden, Netherlands, 1998.

8. Commission Implementing Regulation (EU). EU 2017/1925 of 12 October 2017, Amending Annex I to Counci Regulation (EEC) No 2658/87 on the Tariff and Statistical Nomenclature and on the Common Customs Tariff; Commission Implementing Regulation (EU): Brussels, Belgium, 2017.

9. Food and Forestry Policies (MIPAAF). Update of the National List of Traditional Agri-Food Products Pursuant to Article 12, Paragraph 1, of the Law of 12 December 2016, n. 238; Ministry of Agricolture: Roma, Itay, 2018.

10. Angioni, A.; Cau, A.; Addis, P. Gas chromatographic mass spectrometry determination of geosmin and 2-methylisoborneol off-Flavor in Mugil cephalus roe. Food Anal. Methods 2014, 8, 6. [CrossRef]

11. FAO Fisheries and Aquaculture Department Rome. FAO Major Fishing Areas. Available online: http: //www.fao.org/fishery/area/search/en (accessed on 4 April 2020).

12. Barra, A.; Garau, V.L.; Dessi, S.; Sarais, G.; Cereti, E.; Arlorio, M.; Coisson, J.D.; Cabras, P. Chemical characterization and DNA tracking of Sardinian botargo by Mugil cephalus from different geographical origins. J. Agric. Food Chem. 2008, 56, 10847-10852. [CrossRef] [PubMed]

13. Locci, E.; Piras, C.; Mereu, S.; Cesare Marincola, F.; Scano, P. 1H NMR Metabolite fingerprint and pattern recognition of Mullet (Mugil cephalus) Bottarga. J. Agric. Food Chem. 2011, 59, 9497-9505. [CrossRef]

14. Scano, P.; Rosa, A.; Locci, E.; Dessì, M.A.; Lai, A. NMR study of the lipid profile of mullet raw roe and bottarga. Eur. J. Lipid Sci. Technol. 2009, 11, 505-512. [CrossRef]

15. Scano, P.; Rosa, A.; Locci, E.; Manzo, G.; Dessì, M.A. Modifications of the 1H NMR metabolite profile of processed mullet (Mugil cephalus) roes under different storage conditions. Magn. Reson. Chem. 2012, 50, 436-442. [CrossRef]

16. Çelik, U.; Altınelataman, C.; Dinçer, T.; Acarlı, D. Comparison of Fresh and Dried Flathead Grey Mullet (Mugil cephalus, Linnaeus 1758) Caviar by means of Proximate Composition and Quality Changes during Refrigerated Storage at $4 \pm 2{ }^{\circ} \mathrm{C}$. Turk. J. Fish. Aquat. Sci. 2012, 12, 1-5. [CrossRef]

17. Caredda, M.; Addis, M.; Pes, M.; Fois, N.; Sanna, G.; Piredda, G.; Sanna, G. Physico-chemical, colorimetric, rheological parameters and chemometric discrimination of the origin of Mugil cephalus' roes during the manufacturing process of bottarga. Food Res. Int. 2008, 108, 128-135. [CrossRef]

18. Murenu, M.; Olita, A.; Sabatini, A.; Follesa, M.C.; Cau, A. Dystrophy effects on the Liza ramada (Pisces, Mugilidae) population in the Cabras lagoon (Central-Western Sardinia). Chem. Ecol. 2004, 20, 425-433. [CrossRef]

19. Cataudella, S.; Crosetti, D.; Massa, F. Mediterranean coastal lagoons: Sustainable management and interactions among aquaculture, capture fisheries and the environments. Int. Stud. Rev. 2015, 95, 1-294.

20. Padedda, B.M.; Pulina, S.; Magni, P.; Sechia, N.; Luglie, A. Phytoplankton dynamics in relation to environmental changes in a phytoplankton-dominated Mediterranean lagoon (Cabras Lagoon, Italy). Adv. Oceanogr. Limnol. 2012, 3, 147-169. [CrossRef]

21. World Organization of Animal Health. Welfare Aspects of Stunning and Killing of Farmed Fish for Human Consumption. Available online: https://www.oie.int/en/standard-setting/aquatic-code/access-online/ (accessed on 20 September 2020). 
22. Corrias, F.; Atzei, A.; Addis, P.; Secci, M.; Russo, M.; Angioni, A. Integrated environmental evaluation of heavy metals and metalloids bioaccumulation in invertebrates and seaweeds from different marine coastal areas of Sardinia, Mediterranean Sea. Environ. Pollut. 2020, 266, 115048. [CrossRef] [PubMed]

23. Beach, L.M. Determination of As, Sb and Se in Difficult Environmental Samples by Hydride Generation. Available online: https://www.agilent.com/cs/library/applications/aa105.pdf (accessed on 3 October 2020).

24. Evans, S.J.; Johnson, M.S.; Leah, R.T. Determination of Mercury in Fish Tissue, a Rapid, Automated Technique for Routine Analysis. Available online: https://www.agilent.com/cs/library/applications/AA060. pdf (accessed on 3 October 2020).

25. Wenzl, T.; Haedrich, J.; Schaechtele, A.; Robouch, P.; Stroka, J. Guidance Document on the Estimation of LOD and LOQ for Measurements in the Field of Contaminants in Feed and Food. EUR 28099; Publications Office of the European Union: Luxembourg, 2016.

26. Srigley, C.T.; Mossoba, M.M. Current Analytical Techniques for Food Lipids. In Food Safety: Innovative Analytical Tools for Safety Assessment; Spizzirri, U.G., Cirillo, G., Eds.; Scrivener Publishing LLC: Beverly, MA, USA, 2017.

27. Atherton, H.J.; Bailey, N.J.; Zhang, W.; Taylor, J.; Major, H.; Shockcor, J.; Clarke, K.; Griffin, J.L. A combined 1H NMR spectroscopy and mass spectrometry-based metabolomic study of the PPAR-null mutant mouse defines profound systemic changes in metabolism linked to the metabolic syndrome. Physiol. Genomics 2006, 27, 178-186. [CrossRef] [PubMed]

28. Pigott, G.M.; Tuker, B.W. Fish oils. In Encyclopaedia of Food Sciences and Nutrition, 2nd ed.; Elsevier: Amsterdam, The Netherlands, 2003; Volume 4, pp. 2491-2501.

29. Chomérat, N.; Garnier, R.; Bertrand, C.; Cazaubon, A. Seasonal succession of cyanoprokaryotes in a hyperetrophic oligo-mesohaline lagoon from the South of France. Estuar. Coast. Shelf Sci. 2007, 72, 591-602. [CrossRef]

30. Pulina, S.; Padedda, B.M. The dominance of cyanobacteria in Mediterranean hypereutrophic lagoons: A case study of Cabras Lagoon (Sardinia, Italy). Sci. Mar. 2011, 75, 111-120. [CrossRef]

31. Scheffer, M.; Rinaldi, S.; Gragnani, A.; Mur, L.R.; Van Nes, E.H. On the dominance of filamentous cyanobacteria in shallow. Turbid Lakes. Environ. 2007, 78, 272-282.

32. Sorokin, Y.I.; Sorokin, P.Y.; Gnes, A. Structure and functioning of antropogenically transformed Comacchio lagoon ecosystem (Ferrara, Italy). Mar. Ecol. Prog. Ser. 1996, 133, 57-71. [CrossRef]

33. Hafez, N.E.; Awad, A.M.; Ibrahim, S.M.; Mohamed, H.R.; El-Lahamy, A.A. Effect of Salting Process on Fish Quality. Nutr. Food Process. 2019, 2. [CrossRef]

34. Lu, J.Y.; Ma, Y.M.; Williams, C.; Chung, R.A. Fatty and amino acid composition of salted mullet roe. J. Food Sci. 1979, 44, 676-677. [CrossRef]

35. Kalogeropoulos, N.; Nomikos, T.; Chiou, A.; Fragopoulou, E.; Antonopoulou, S. Chemical composition of Greek Avgotaracho prepared from mullet (Mugil cephalus): Nutritional and health benefits. J. Agric. Food Chem. 2008, 56, 5916-5925. [CrossRef] [PubMed]

36. Scano, P.; Rosa, A.; Cesare Marincola, F.; Locci, E.; Melis, M.P.; Dessì, M.A.; Lai, A. 13C NMR, GC and HPLC characterization of lipid components of the salted and dried mullet (Mugil cephalus) roe "bottarga". Chem. Phys. Lipids 2008, 151, 69-76. [CrossRef]

37. Gallagher, M.L.; McLeod, S.H.; Rulifson, R. Seasonal variations in fatty acids of striped bass Morone saxatilis. J. World Aquac. Soc. 1989, 20, 38-45. [CrossRef]

38. Wirth, M.; Kirschbaum, F.; Gessner, J.; Williot, P.; Patriche, N.; Billard, R. Fatty acid composition in sturgeon caviar from different species: Comparing wild and farmed origins. Int. Rev. Hydrobiol. 2002, 87, 629-636. [CrossRef]

39. Porarinsdottir, K.A. The Influence of Salting Procedures on the Characteristics of Heavy Salted Cod. Ph.D. Thesis, Lund University, Lund, Sweden, 2010.

40. Amir, R.M.; Randhawa, M.A.; Sajid, M.W.; Nadeem, M.; Ahmad, A.; Watto, F.M. Evaluation of various soaking agents as a novel tool for heavy metal residues mitigation from spinach. Food Sci. Technol. 2019, 39, 76-180. [CrossRef]

41. Oluk, C.A.; Karaca, O.B. Functional food ingredients and nutraceuticals, milk proteins as nutraceuticals nanoscience and food industry. In Nutraceuticals, Nanotechnology in the Agri-Food Industry; Grumezescu, M.A., Ed.; Elsevier: Amsterdam, The Netherlands, 2016; Volume 4. 
42. Shirai, N.; Higuchi, T.; Suzuki, H. Analysis of lipid classes and the fatty acid composition of the salted fish roe food products, Ikura, Tarako, Tobiko, and Kazunoko. Food Chem. 2006, 94, 61-67. [CrossRef]

43. McDougle, D.R.; Watson, J.E.; Abdeen, A.A.; Adili, R.; Caputo, M.P.; Krapf, J.E.; Johnson, R.W.; Kilian, K.A.; Holinstate, M.; Das, A. Anti-inflammatory w-3 endocannabinoid epoxides. PNAS Early Ed. 2017, 114, E6034-E6043. [CrossRef]

44. WHO. Protein and Amino Acid Requirements in Human Nutrition. In WHO Technical Report Series 935. Joint FAO/WHO/UNU Expert Consultation on Protein and Amino Acid Requirements in Human Nutrition; WHO: Geneva, Switzerland, 2002. 